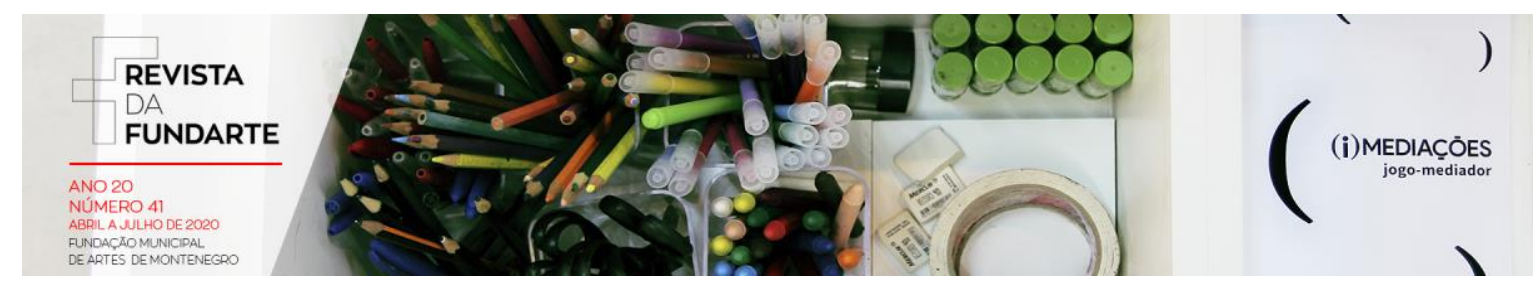

\title{
(I)MEDIAÇÕES: \\ ENCONTROS E EXPERIÊNCIAS COLETIVAS NO ESPAÇO EXPOSITIVO
}

\author{
Mariah de Godoy Pinheiro
}

DOI: http://dx.doi.org/10.19179/2F2319-0868.811

PINHEIRO, Mariah de Godoy. (I)Mediações: Encontros e experiências coletivas no espaço expositivo. Revista da FUNDARTE. Montenegro, p.01-09, ano 20, oㅡ 41, Abril/Junho de 2020.

Disponível em: http://.seer.fundarte.rs.gov.br/index.php/RevistadaFundarte/index> 30 de junho de 2020. 


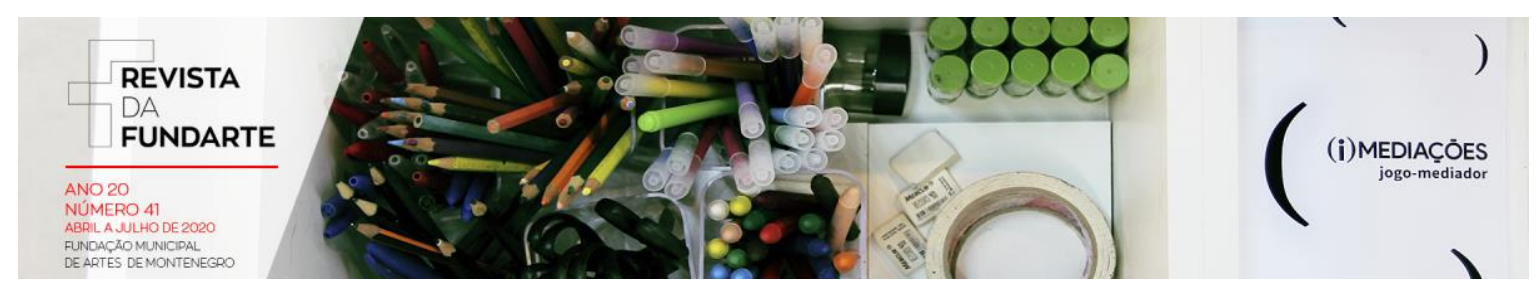

\title{
(I)MEDIAÇÕES: \\ ENCONTROS E EXPERIÊNCIAS COLETIVAS NO ESPAÇO EXPOSITIVO
}

\author{
Mariah de Godoy Pinheiro ${ }^{1}$ \\ Universidade Estadual do Rio Grande do Sul/RS
}

Resumo: Este ensaio apresenta reflexões que foram propulsoras na elaboração da pesquisa e produção poética "(i)mediações: encontros e experiências coletivas no espaço expositivo", que teve como base a criação do conceito (i)mediações e de um jogo propositor.

Palavras-chave: Artes Visuais; Educação; Mediação.

\section{(I)MEDIACIONES:}

\section{REUNIONES Y EXPERIENCIAS COLECTIVAS EN EL ESPACIO EXPOSITIVO}

Abstract: This essay presents reflections that were propelling in the elaboration of research and poetic production "(i)mediations: meetings and collective experiences in the exhibition space", which was based on the creation of a propositional game and the concept (i)mediations.

Keywords: Visual arts; Education; Mediation.

A pesquisa "(i)mediações: encontros e experiências coletivas no espaço expositivo", foi concebida como Trabalho de Conclusão de Curso $^{2}$ em artes visuais na Universidade Estadual do Rio Grande do Sul ${ }^{3}$, no segundo semestre de 2019, se caracterizando como uma investigação e produção artística em poéticas visuais, cujo o trabalho se encontra em exibição na mostra das proposições dos formandos ${ }^{4}$, na Galeria de Arte Loide Schwambach, da Fundação Municipal de Artes de Montenegro, onde situa-se a unidade das Artes da UERGS.

No momento em que desenvolvia esta pesquisa, minha rotina girava em torno: da universidade do estado, cursando licenciatura em artes visuais; de uma

\footnotetext{
${ }^{1}$ Graduanda em artes visuais: licenciatura pela Universidade Estadual do Rio Grande do Sul/ UERGS.

${ }^{2}$ Formato de TCC que atende ao Plano Pedagógico de Curso da Graduação em Artes Visuais da UERGS de 2006, que foi atualizado em 2018.

3 Universidade Estadual do Rio Grande do Sul - Unidade em Montenegro, RS.

${ }^{4}$ Exposição Salas/Edição 4 - Galeria de Arte Loide Schwambach, da Fundação Municipal de Artes de Montenegro
}

PINHEIRO, Mariah de Godoy. (I)Mediações: Encontros e experiências coletivas no espaço expositivo. Revista da FUNDARTE. Montenegro, p.01-09, ano 20, oㅡ 41, Abril/Junho de 2020.

Disponível em: http://.seer.fundarte.rs.gov.br/index.php/RevistadaFundarte/index> 30 de junho de 2020. 


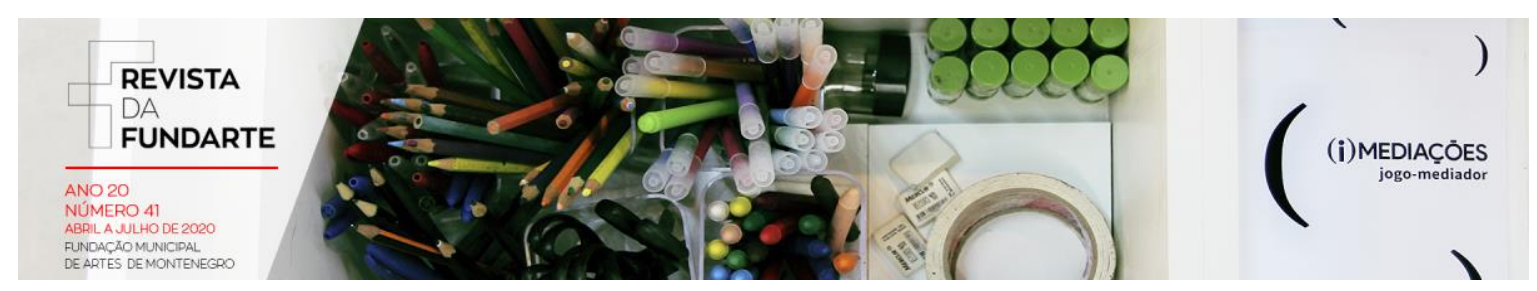

escola pública ${ }^{5}$, cumprindo estágio obrigatório no ensino médio; do museu de arte do estado ${ }^{6}$, como estagiária em seu núcleo educativo, e de uma escola municipal ${ }^{7}$, através de um projeto $^{8}$ de artes visuais, financiado por uma fundação cultural da rede privada. Durante esse ciclo de atividades em diferentes tipos de instituições onde ocorre a ligação entre educação e artes visuais, percebi não só a importância do acesso dos públicos aos espaços culturais de arte, mas também da ação mediadora, no que diz respeito ao acolhimento de encontros e às possibilidades de gerar experiências e sentidos coletivos ao estar/ocupar esses espaços.

Assim, o ponto de partida para elaboração da pesquisa foi sobre como repensar as formas de participação e como promover práticas poéticas de convívio e trocas em exposições de arte, levando em consideração as potências pedagógicas dos trabalhos artísticos expostos e a importância das diferentes relações produzidas pelos múltiplos públicos para que esses locais e trabalhos tenham seus sentidos ampliados.

Partindo dessas perspectivas, o projeto foi pensado a partir da galeria ou qualquer espaço artístico-expositivo como lugares de encontro, propondo a questão: como artista, de que modo seria possível intermediar encontros entre públicos e obras nos espaços expositivos?

Com base nessa questão, a ideia de (i)mediações, presente desde o título, joga com as palavras imediação e mediação, trazendo um duplo sentido a partir de suas definições. No dicionário ${ }^{9}$, imediação indica redondeza, área que se localiza ao redor de um lugar. Também pode-se definir o termo como um estado ou qualidade de proximidade, contrário de distância. Nesse sentido, pergunto: que fronteiras existem entre artista, obra, público e museu/galeria, e o que se encontra nas suas

\footnotetext{
5 Escola Estadual de Ensino Médio Ceará - Porto Alegre, RS.

${ }^{6}$ Museu de Arte do Rio Grande do Sul Ado Malagoli - Porto Alegre, RS.

7 Escola Municipal de Ensino Fundamental Leocádia Felizardo Prestes - Porto Alegre, RS.

8 Projeto Iberê nas Escolas, financiado pela Fundação Iberê Camargo em parceria com a Prefeitura de Porto Alegre.

${ }^{9}$ Conforme definição do Minidicionário da Língua Portuguesa Houaiss, 2004.
}

PINHEIRO, Mariah de Godoy. (I)Mediações: Encontros e experiências coletivas no espaço expositivo. Revista da FUNDARTE. Montenegro, p.01-09, ano 20, no 41, Abril/Junho de 2020.

Disponível em: http://.seer.fundarte.rs.gov.br/index.php/RevistadaFundarte/index> 30 de junho de 2020. 


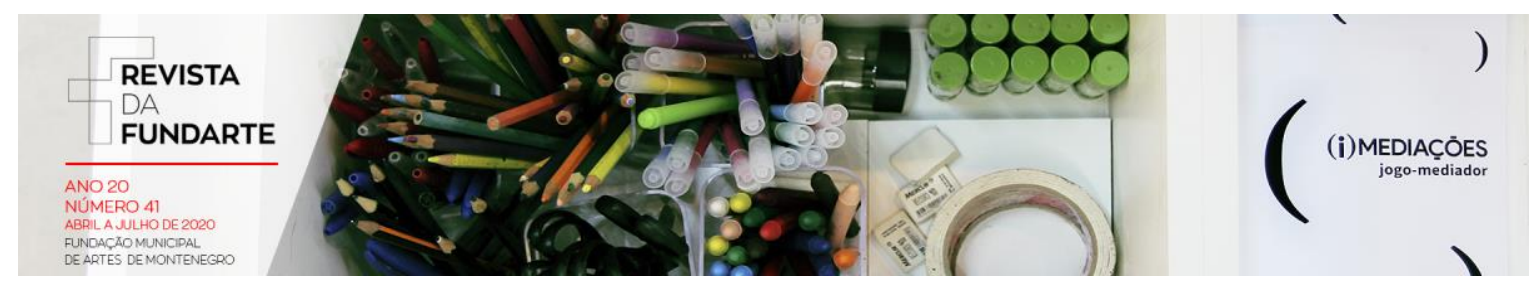

imediações? Gabriel Pérez Barreiro, curador da 6 $6^{\underline{a}}$ Bienal do Mercosul, comenta sobre a ação de comunicação entre público e obra da seguinte forma:

[...] se pensamos na imagem de alguém olhando uma obra de arte qualquer, o que está acontecendo? Onde está o conteúdo? Acredito que não está nem na obra de arte, que precisa do espectador, nem no espectador, que precisa da obra de arte. Na realidade, é no espaço entre os dois que a comunicação é gerada, nesse espaço aparentemente vazio. A obra é uma margem, e o espectador outra. Os dois precisam ser valorizados para criar a possibilidade da terceira, uma margem que é temporária, ativa, crítica, e por isso, profundamente pedagógica. (PÉREZ BARREIRO, 2009, p. 109).

A palavra mediação - no que o próprio termo sugere - é a ação de estar no meio, ocupando a zona constituída por esse conjunto de relações entre o espaço expositivo, a obra, o artista e os públicos. A pesquisadora Mirian Celeste Martins, no caderno da Política Nacional de Educação Museal (2018, p. 85), define mediação como interação e diálogo que valoriza e dá voz ao outro na busca de uma maior aproximação com os objetos e as manifestações artísticas.

Levando em conta minhas experiências enquanto mediadora, identifiquei na mediação um trabalho coletivo, participativo e criativo, reconhecendo que há uma dimensão poética na ação destes encontros. Com isso, a proposição desta pesquisa em poéticas visuais veio a ser uma prática artística que perpasse a interface da participação, com a intenção de desprender os públicos da posição de espectadores. Mas, para além disso, teve como principal objetivo a inter-relação da mediação, na qual ocorre a invenção de sentidos coletivos, possibilitando que as pessoas elaborem suas formas singulares de vivenciar os objetos e os espaços de arte.

Dessa forma, no planejamento dessas (i)mediações pretendeu-se criar condições de encontros e trocas, através da ação mediativa de um jogo propositor, como um dispositivo artístico pedagógico de uso coletivo em espaços expositivos. A elaboração do jogo foi composta durante o processo de pesquisa, como um exercício de pesquisa de campo, consistindo na observação da experiência diária das ações mediativas realizadas tanto na escola quanto no museu.

PINHEIRO, Mariah de Godoy. (I)Mediações: Encontros e experiências coletivas no espaço expositivo. Revista da FUNDARTE. Montenegro, p.01-09, ano 20, o 41, Abril/Junho de 2020.

Disponível em: http://.seer.fundarte.rs.gov.br/index.php/RevistadaFundarte/index> 30 de junho de 2020. 


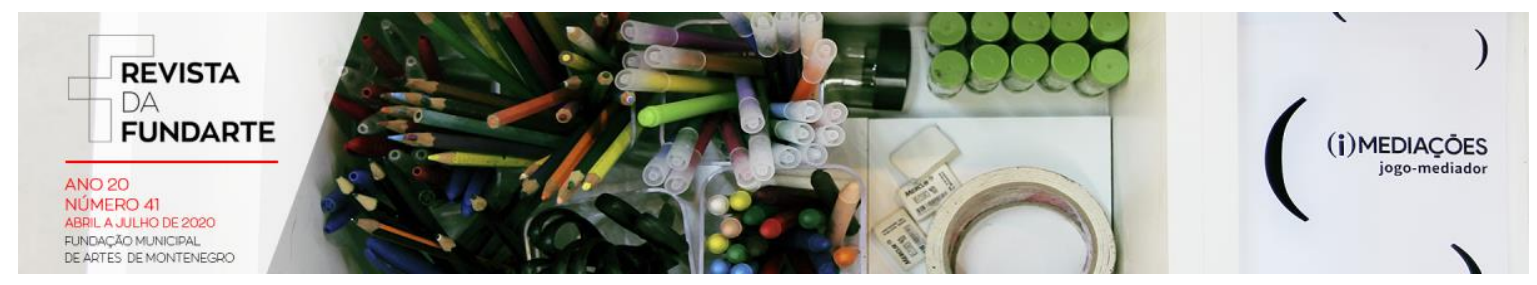

Na maioria das vezes, nesses locais, a imagem do mediador é associada a quem faz a leitura literal dos conteúdos artísticos para o espectador. Essa visão faz com que a mediação ainda seja frequentemente chamada de: visita monitorada, guiada, conduzida ou, até mesmo, dirigida. Tais denominações reforçam a ideia de que a mediação nos espaços de arte está baseada apenas na transmissão das concepções artísticas em exposição, como uma prática de leitura e de direcionamento de percepções únicas, passando exclusivamente por conteúdos históricos, artísticos ou técnicos. Da mesma forma, quem leciona arte em escolas, é entendido como figura detentora e disseminadora desse conjunto de saberes práticos, discursivos e informativos.

Ambas visões demonstram essa via única de emissor-receptor, em uma certa indiferença para o que vem do outro lado, especificamente para as diferentes formas que cada sujeito possui de produzir conhecimento e de experienciar a arte. Dessa forma, qual o sentido da educação em arte estar atrelada apenas à informação, gerando redes de transmissão tão hegemônicas e até mesmo colonizadoras?

A partir desse problema, uma das intenções da pesquisa foi de deslocar o sentido dado ao mediador/professor de arte como transmissor de informações para a condição de propositor de experiências, tornando-se sujeito participante e criador junto aos públicos, os quais deixam de ser meros receptores, para se tornarem importantes agentes de construção de sentidos e conhecimentos em uma exposição. Sob essa perspectiva, ao sair da zona da informação e da discursividade, abre-se espaço para que os visitantes se sintam aptos a criar, comentar, reconsiderar hipóteses e fazer novas investigações sobre uma proposição artística. Desse modo, são propiciadas experiências em arte com bases mais democráticas, gerando novos significados ao se desprender de concepções únicas, integrando, assim, diferentes formas de vivenciar a arte.

Ao considerar essas questões e evocando novamente minhas experiências enquanto docente e mediadora, percebi que, em ambas posições, a construção de aprendizados e significados em arte se dá no processo coletivo. Observo, ainda, o Revista da FUNDARTE. Montenegro, p.01-09, ano 20, no 41, Abril/Junho de 2020.

Disponível em: http://.seer.fundarte.rs.gov.br/index.php/RevistadaFundarte/index> 30 de junho de 2020. 


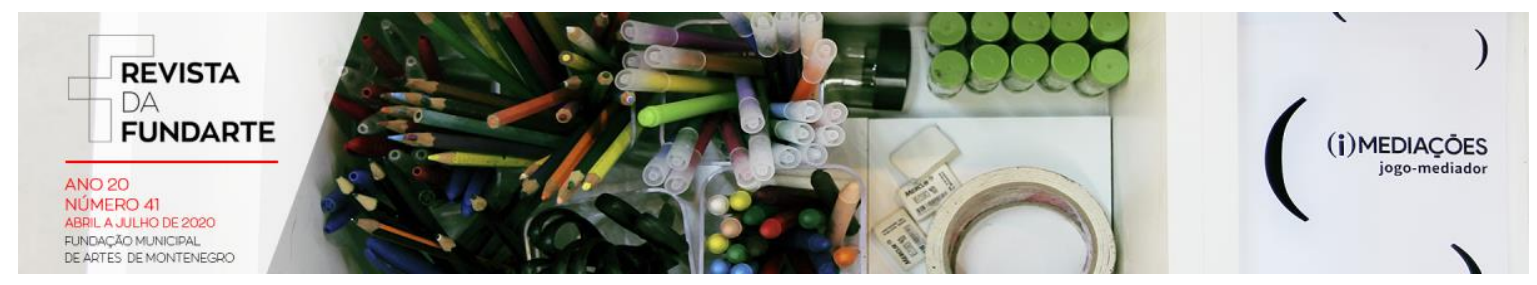

quanto a experiência educativa de levar uma turma de alunos ao museu pode ser transformadora e que, ao reunir um grupo e debater estética por meio de diferentes pontos de vista, também estamos debatendo ética. Nessas ligações, muito além da decodificação de uma obra de arte, a experiência estética nos leva a interpretações, gerando modos de integração de saberes, discutindo, problematizando e nos permitindo uma apreensão tanto da arte quanto da vida.

Dito isso e considerando que cada pessoa carrega conhecimentos e experiências de vida distintos, reforço que não há razão em estabelecer visões ímpares sobre a arte ou sobre qualquer trabalho artístico. Dessa forma, penso que os agentes da arte devem atuar, principalmente, para tornar os encontros em arte mais acessíveis, isto é, para que diferentes mundos possam conviver e integrar aprendizados através das suas próprias imediações, permitindo que as relações com a arte aconteçam de modo mais horizontal e pessoal.

Nesse sentido, prefiro me referir à mediação como ação mediativa, na qual a ação do encontro convoca os públicos a mudar sua posição de visitante-receptor para se colocar em um papel ativo. Desse modo, os públicos, a partir das suas relações com o mundo, podem transformar as convenções das obras e das exposições artísticas, provocando modos de construir conhecimento em arte por meio de diálogos e trocas coletivas. Assim, é possível garantir a singularização e a pluralidade cultural da arte e de cada sujeito, sem hierarquia de posições.

Portanto, a condição e o intuito da pesquisa não teve ênfase na figura do mediador, assim como, a do artista, do curador ou do professor. A ideia tratou-se justamente de tirar o protagonismo de uma figura única, trazendo a proposta de que mediação é o estar entre, entre tantos lugares e interlocutores que movimentam as camadas de sentidos e significações da arte. Significa analisar a mediação como uma prática poética de convívio, de compartilhamento e de produção coletiva.

A proposta do jogo foi composta, especialmente, por esse modo de compreender a mediação em arte, tendo como principal objetivo encontros de trocas coletivas em arte por meio das diferentes relações que podem acontecer entre as Revista da FUNDARTE. Montenegro, p.01-09, ano 20, no 41, Abril/Junho de 2020.

Disponível em: http://.seer.fundarte.rs.gov.br/index.php/RevistadaFundarte/index> 30 de junho de 2020. 


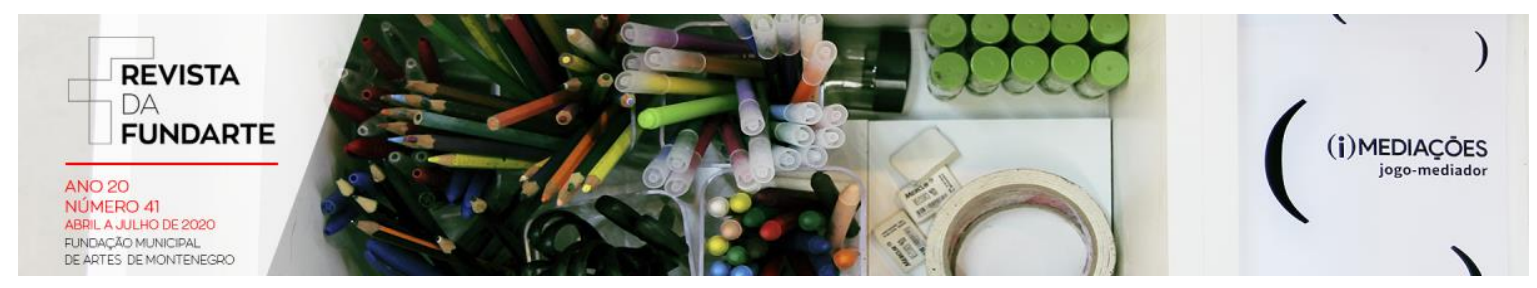

pessoas e o que se encontra exposto em uma exposição. Dessa forma, o que está em questão não é o que pode ser explicado ou compreendido por uma obra através de informações formais, técnicas e teóricas da arte ou do artista, mas, sim, a investigação e a experiência coletiva de estar junto em um encontro com a arte, no qual cada um pode ensinar e aprender alguma coisa a partir das proposições de troca do jogo.

Sua configuração se dá através de uma caixa cúbica branca, fazendo alusão ao habitual cubo branco das exposições. Ao observar a caixa, os possíveis participantes irão encontrar na tampa a primeira proposição-convite: "Vamos abrir experiências coletivas neste espaço?"; ao destampá-la, em sua parte interna há compartimentos com um manual de instruções, sete cartas propositivas e alguns materiais para registro das reverberações das experiências do jogo. Como um dos seus principais objetivos é tirar as pessoas de uma ocupação passiva, individual e contemplativa nos espaços expositivos, não há uma versão para se jogar sozinho, visto que a experiência do jogo é justamente o modo coletivo, no qual cada participante provoca o outro, percorrendo conjuntamente os desafios das cartas e descobrindo múltiplos sentidos da arte por meio da relação com o outro.

As proposições das cartas foram desenvolvidas com inspiração em estratégias pedagógicas utilizadas em mediações e em ações espontâneas dos públicos presenciadas em encontros de mediação. Assim como as cartas, as instruções do jogo foram programadas em equivalência com a ação mediativa. Portanto, não consistem em uma lógica programada ou em um fim pré-determinado. Os percursos são resultados do tempo de encontro, do acaso das escolhas, dos diálogos e das variadas relações e conexões que cada grupo produzir.

Abrem-se, então, propostas para estimular os participantes a vivenciarem o espaço em uma relação próxima, lúdica, curiosa e provocadora de reflexões sobre arte, sobre si e sobre o outro, sobre os possíveis modos de convivência nesse espaço. Desse modo, (i)mediações é um dispositivo aberto que procura provocar experiências diferentes a cada vez que um grupo de pessoas o utiliza, tendo como Revista da FUNDARTE. Montenegro, p.01-09, ano 20, no 41, Abril/Junho de 2020.

Disponível em: http://.seer.fundarte.rs.gov.br/index.php/RevistadaFundarte/index> 30 de junho de 2020. 


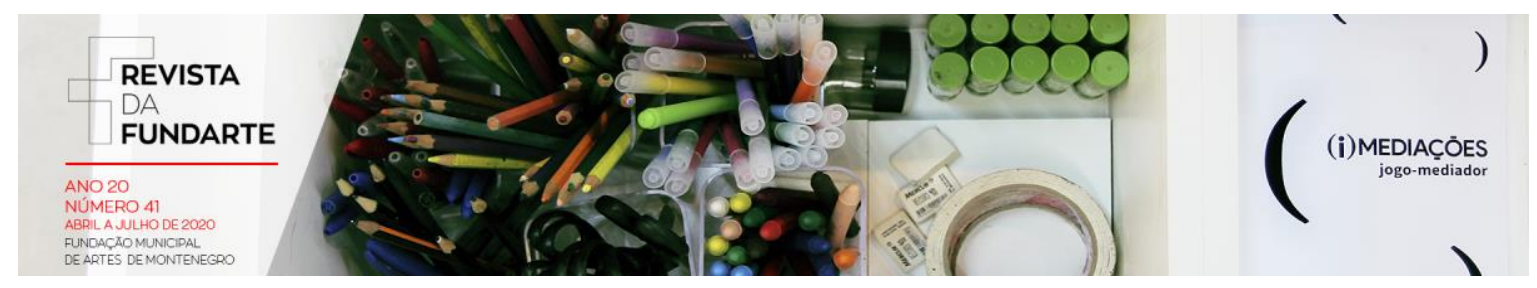

base os repertórios e referências pessoais de cada indivíduo, podendo estabelecer, assim, compartilhamentos de diferentes ideias e saberes, gerando aprendizado e conhecimento coletivo através de ações e trocas em arte.

O jogo termina quando se encerram as sete proposições, em torno de uma a duas horas, tempo em que normalmente acontece um encontro mediado, podendo terminar antes, quando o grupo entender como concluída a experiência. Ao finalizar o jogo, haverá alguns registros das ações (fotográficos, escritos, desenhos), podendo estes serem transformados, interligados e estruturados como um mapa de ideias coletivo, a partir do papel-mapa que compõe o conjunto de materiais de registro disponibilizados no jogo.

A proposta do mapa surge como um modo de registro e compartilhamento das derivações de experiências de cada grupo que participa, convocando a ideia de que cada encontro pode mapear diferentes (i)mediações, nas quais os diferentes mundos podem conviver, articulando saberes e gerando intercâmbios de aprendizados com base nas relações em arte. A cada grupo, a exposição já não é mais a mesma do encontro anterior, pois no momento em que os públicos trazem suas (i)mediações para dentro da galeria/museu, ela é transformada e, assim, cada experiência de encontro mediativo constitui uma forma de intervenção e criação poética coletiva e integrante da exposição.

Finalizo esse recorte da pesquisa reafirmando a importância no que diz respeito a dar espaço à comunicação, à troca e à valorização de formas ativas, afetivas e coletivas de ocupar e (re)significar os espaços da arte, possibilitando diferentes relações e percepções nos espaços expositivos e entendendo esses lugares não como meros espaços de contemplação, mas de possíveis convívios, compartilhamentos e aprendizagens. Revista da FUNDARTE. Montenegro, p.01-09, ano 20, no 41, Abril/Junho de 2020.

Disponível em: http://.seer.fundarte.rs.gov.br/index.php/RevistadaFundarte/index> 30 de junho de 2020. 


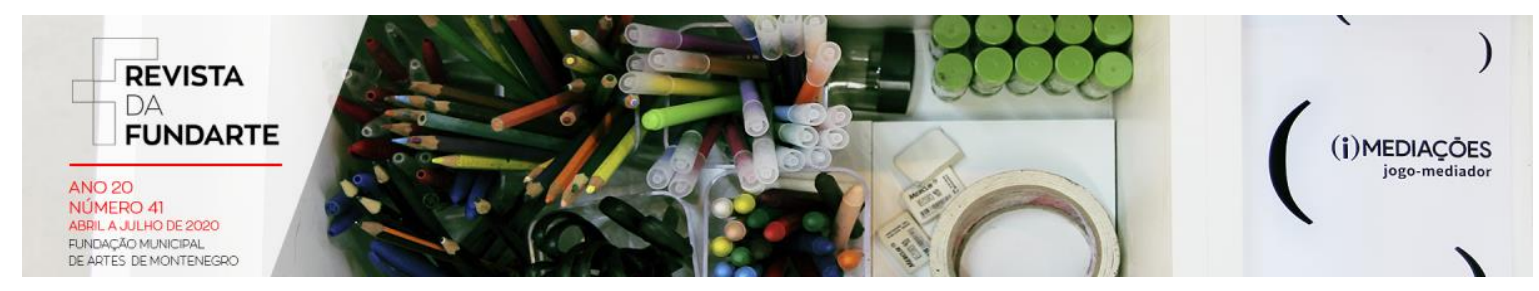

\section{Referências:}

PÉREZ-BARREIRO, Gabriel. Público para a arte / Arte para o público. In: PÉREZBARREIRO, Gabriel; CAMNITZER, Luis (org.). Educação para a arte / Arte para a educação. Porto Alegre: Fundação Bienal do Mercosul, 2009.

MINIDICIONÁRIO DA LÍNGUA PORTUGUESA HOUAISS, 2. ed., Rio de Janeiro: Objetiva, 2004. 